\title{
ISO Standards: A Platform for Achieving Sustainable Development Goal 2
}

\author{
Xiaoli Zhao ${ }^{1}$, Pavel Castka ${ }^{1, * \mathbb{C}}$ and Cory Searcy ${ }^{2}$ \\ 1 UC Business School, University of Canterbury, Christchurch 8041, New Zealand; lillianzhaoxl@gmail.com \\ 2 Department of Mechanical and Industrial Engineering, Ryerson University, Toronto, ON M5B 2K3, Canada; \\ cory.searcy@ryerson.ca \\ * Correspondence: pavel.castka@canterbury.ac.nz; Tel.: +64-33693761
}

Received: 16 October 2020; Accepted: 5 November 2020; Published: 10 November 2020

\begin{abstract}
The International Organization for Standardization (ISO) has recently begun promoting the linkages between its standards and the United Nations' Sustainable Development Goals (SDGs). However, further research is needed to explore how ISO standards can serve as a platform for achieving the SDGs. In this paper, we discuss the interlinkage between ISO standards and SDG 2 (i.e., Zero hunger-End hunger, achieve food security and improved nutrition, and promote sustainable agriculture). We review the literature on a set of 77 ISO standards related to SDG 2 and study existing evidence pertinent to SDG 2 and its targets. Specifically, we review research in four key areas of interest: agricultural productivity of ISO certified firms, adoption of ISO standards amongst small scale producers, ISO standards development, and governance of standards. We found implicit evidence in the literature that ISO standards have the potential to contribute to two SDG 2 targets, namely targets 2.3 and 2.4. Some aspects of ISO standards, however, such as low levels of adoption amongst small scale farmers or a lack of multi-stakeholder standard development, contradict key aspects of the SDG agenda. We outline key areas for future research in the four areas of interest noted above.
\end{abstract}

Keywords: ISO; standards; sustainable development goals; SDG 2; sustainable development

\section{Introduction}

The adoption of the United Nations' 2030 Agenda and its accompanying 17 Sustainable Development Goals (SDGs) by 193 heads of state in 2015 has been celebrated in academic, activist, business, and policy circles as a means to stimulate a radical shift in world affairs [1]. The SDGs closely link "sustainability" with "development" through the principles of "universality", "integration", and "leave no one behind". However, the SDGs are not legally binding (i.e., governments are expected to take ownership and establish national frameworks for the achievement of these global goals), and political leaders around the world have not fully clarified the 2030 Agenda. For example, a clear distinction of the responsibilities of various stakeholders, including national governments, international agencies, and businesses, has yet to be made [2]. In 2019, Secretary-General António Guterres emphasized that "so far, we are not keeping pace", in part due to poor financing of the SDG agenda in the developing world [3]. Jabbari, et al. [4] demonstrate that the progress in developing countries has been minimal. Due to the impact of the COVID-19 pandemic, the resourcing of the SDG agenda might become even more challenging. Therefore, finding new ways to progress with the SDGs is of paramount importance. One of the tangible mechanisms to help achieve the SDGs is through implementation of the standards developed by the International Organization for Standardization (ISO) and the existing quality infrastructure that has been already adopted across the globe. 
ISO has developed standards that address practically all aspects of societal functioningfrom standards on food systems to standards on medical devices to name just a few. With over 20,000 standards that are used in 162 member countries [5], ISO standards play a significant role in international trade and international relationships, as well as in domestic affairs [6]. ISO is the largest standards developer in the world, and its standards ensure consistency and transparency, as well as a transfer of best practices across the globe [7]. ISO has been influential in determining key principles and practices of sustainability through a set of standards, including "air, water and soil quality, on emissions of gases and radiation, and environmental aspects of products" [8]. New standards-such as ISO 20400 on sustainable procurement or standards that harmonize electric vehicles' infrastructure [9]—continue to emerge, which suggests that the impact of ISO standards in this domain will continue to grow. ISO has been similarly active in the food domain. ISO has developed over 1600 standards for different aspects of the food sector, including the ISO 22000 standard for food safety management systems that has been adopted in more than 39,000 organizations worldwide [10].

Given the influence that ISO Standards have in the global marketplace on the one hand, and the importance of the SDG agenda on the other, it is timely to consider the linkages between ISO Standards and the SDGs. In this paper, we aim to determine the potential of ISO standards to address SDG 2-operationalizing the potential in terms of standards development, adoption, impact, and governance [11] — and analyzing that potential from the perspective of the SDG 2 targets. We focus specifically on SDG 2 Zero hunger which, according to the Food and Agriculture Organization of the United Nations, is key to the success of the entire SDG agenda [12]. To fulfill our aim, we conduct a systematic literature review and analyze a set of 77 ISO standards for food that are explicitly listed by ISO as exemplar standards that address SDG 2 [13]. Leveraging normative and institutional theoretical perspectives, our analysis focuses on four units of analysis, namely agricultural productivity, adoption of ISO standards, ISO standards development, and governance of standards.

The paper makes several contributions to the literature. First, the paper provides empirical evidence about the contribution of ISO standards to meeting the SDGs. So far, the literature has mainly focused on linking ISO standards that can in principle address the SDGs, but without specifically discussing the congruence and contribution of these standards to meeting the SDGs and their accompanying targets [13]. Second, we discuss and provide guidance on how research in this domain can be advanced, as well as further understanding about how the role and contribution of ISO standards can be further investigated. In our analysis and discussion, we leverage a normative perspective (i.e., discussing the role of standards as reference points and instruments of knowledge codification), as well as an institutional perspective (i.e., the role of infrastructure behind ISO standards, namely, accreditation, certification, and auditing; hence considering ISO standards as instruments of change). Combined, these two perspectives are employed to determine the current status of ISO standards' contribution to the SDGs. Given the universally accepted importance of the UN's SDGs for advancing sustainable development [14], there is a need to enhance and encourage academic research in this domain.

\section{Conceptual Background-ISO Standards and the SDGs}

\subsection{ISO Standards}

ISO Standards contribute to the global economy on multiple fronts, such as providing a springboard to the development of quality infrastructure in national economies, enabling international trade (i.e., by reducing barriers to international trade), enabling business-to-business (B2B) interactions, ensuring consumer safety, and providing a technical basis for regulation and policy making [5].

ISO, as an international standards development organization, consists of representatives from over 160 countries, and provides a strong institutional platform to develop standards. Standards are developed in committees by experts nominated by individual state members or liaison organizations [15]. For instance, the ISO/TC 207 committee is responsible for standardization in the domain of environmental management. These committees produce standards that, if approved, are accepted in 
member countries. Because ISO is purely a developer of standards, other organizations are responsible for the monitoring of ISO's standards adoption and their consistent use. In general, this role is fulfilled by a network of accreditation and conformity assessment bodies (CABs). Whilst accreditation bodies are responsible for overseeing CABs, CABs are responsible for ensuring consistency in adoption of ISO standards by individual organizations. Such monitoring activities are universally employed across the globe [16].

Even though ISO is an international platform for standards development, it should be noted that the standards are also adopted at the national level as national standards. ISO standards are thus directly incorporated to "quality infrastructures" [17], which are "the combination of initiatives, institutions, organizations, activities and people that help ensure products and services meet the requirements of customers" [18]. Although quality infrastructures are not exclusively based on ISO Standards, ISO standards form a critical part and therefore provide an important mechanism to codify and institutionalize knowledge [19].

\subsection{ISO Standards and Food}

ISO Standards for food (numbering about 1600 standards) are designed to create confidence in food products, improve agricultural methods, and promote sustainable and ethical purchasing [13]. The standards cover a number of areas including food products, food safety management, and other food systems-related domains, as well nutritional and safety testing, quality, packaging, and traceability. The development of standards is managed by various committees and subcommittees. A list of the most important committees and key standards that were developed by these committees is provided in Table 1 , which was developed based on the information provided in the recent ISO and Food report [8]. Table 1 also includes sustainability-focused standards that are developed by other committees. Although not primarily focused on food, these standards are often promoted by ISO as part of the list of standards that contribute to SDG 2 [13].

Table 1. ISO Standards for Food.

\begin{tabular}{|c|c|c|}
\hline Typology of Food Systems Standards & Committees & Key Standards \\
\hline Food products & $\begin{array}{l}\text { ISO/TC 34, Food products } \\
\text { ISO/TC 34/SC 5, Milk and milk products } \\
\text { ISO/TC 34/SC 4, Cereals and pulses }\end{array}$ & $\begin{array}{l}\text { ISO 20633, Infant formula and adult } \\
\text { nutritionals-Determination of vitamin E and } \\
\text { vitamin A by normal phase high performance } \\
\text { liquid chromatography }\end{array}$ \\
\hline Food safety management & $\begin{array}{l}\text { ISO/TC 34/SC 17, Management systems } \\
\text { for food safety }\end{array}$ & $\begin{array}{c}\text { ISO 22000, Food safety management } \\
\text { systems-Requirements for any organization in } \\
\text { the food chain }\end{array}$ \\
\hline Microbiology & ISO/TC 34/SC 9, Microbiology & $\begin{array}{l}\text { ISO } 16140, \text { Microbiology of the food } \\
\text { chain-Method validation }\end{array}$ \\
\hline Fisheries and aquaculture & ISO/TC 234, Fisheries and aquaculture & $\begin{array}{l}\text { ISO 12875, Traceability of finfish } \\
\text { products-Specification on the information to be } \\
\text { recorded in captured finfish distribution chains } \\
\text { ISO } 12878 \text {, Environmental monitoring of the } \\
\text { impacts from marine finfish farms on soft bottom }\end{array}$ \\
\hline Essential oils & ISO/TC 54, Essential oils & No standards are listed on the ISO website \\
\hline Starch and its by-products & $\begin{array}{l}\text { ISO/TC 93, Starch (including derivatives } \\
\text { and by-products) }\end{array}$ & No standards are listed on the ISO website \\
\hline Sustainability & $\begin{array}{c}\text { ISO/TC 207, Environmental Management } \\
\text { ISO/TMBG } \\
\text { Technical Management Board-groups } \\
\text { ISO/TC 34, Food products } \\
\text { ISO/TC 34/SC } 18 \text { Cocoa }\end{array}$ & $\begin{array}{l}\text { ISO 14001 Environmental management } \\
\text { systems-Requirements with guidance for use } \\
\text { ISO 26000:2010, Guidance on social responsibility } \\
\text { ISO 20400:2017, Sustainable } \\
\text { procurement—Guidance } \\
\text { ISO/TS 26030:2019, Social responsibility and } \\
\text { sustainable development-Guidance on using } \\
\text { ISO 26000:2010 in the food chain } \\
\text { ISO 34101-1:2019, Sustainable and traceable } \\
\text { cocoa-Part 1: Requirements for cocoa } \\
\text { sustainability management systems }\end{array}$ \\
\hline
\end{tabular}




\subsection{Sustainable Development Goals (SDGs)}

A widely accepted definition of Sustainable Development is "development that meets the needs of the present without compromising the ability of future generations to meet their own needs" [20]. The use of this definition focuses on intra- and intergenerational equity. The definition implies a continued emphasis on economic growth, while also requiring a greater focus on equity, which could include providing greater resources to the poor and encouraging effective citizen participation [21]. Furthermore, this concept also implies limits imposed by the present state of technology and social organization on environmental resources, as well as by the ability of the biosphere to absorb the effects of human activities [21]. Thus, defining a unified set of SDGs is challenging, especially when there can be conflict between individual goals, such as energy provision and climate-change, particularly with the human population set to rise to 9 billion by 2050 [22].

In September 2015, the United Nations (UN) General Assembly adopted 17 Sustainable Development Goals (SDGs) as an integral part of the 2030 Agenda for Sustainable Development [23]. The SDGs mark a historic shift for the UN towards one sustainable development agenda, finally integrating economic and social development with environmental sustainability, as well as placing sustainability goal-setting at the center of global policy and governance [23]. The SDG agenda addresses critical aspects of sustainable development related thematic issues, including water, energy, climate, oceans, urbanization, transport, science, and technology. The goals are conceptualized by individual targets and indicators that serve to monitor progress and that progress is reported through the UN's website and through UN's reports.

\subsection{Sustainability Development Goal 2-Zero Hunger}

Throughout the world, more than 820 million people suffer from daily hunger and this number has been slowly increasing in the past three years [24]. The problems with malnutrition and food availability are further exacerbated by the COVID-19 pandemic [25]. The UN report of the Secretary-General Progress towards the Sustainable Development Goals suggests that small scale producers were hit particularly hard by the pandemic and points out that sharp increases in food prices were concentrated largely in sub-Saharan Africa and that "aid to agriculture in developing countries fell, from nearly 25 per cent of all donors' sector-allocable aid in the mid-1980s to only 5 per cent, in 2018" [26]. Apart from hunger and malnutrition, the world is also facing the growing threat of people being overweight and obese [1].

Hunger and food insecurity are the products of a complex set of factors, including climate-related triggers (e.g., drought, flood, cyclone), which are often further exacerbated by economic hardship and conflict [1]. SDG 2 aims to "end hunger, achieve food security and improved nutrition and promote sustainable agriculture" [27]. SDG 2 Zero hunger is operationalized by eight targets [28]. The overview of the targets (based on information from UN's website [29]) is provided in Table 2.

The SDG 2 Targets combine broad societal issues (i.e., undernourishment), industry related issues (i.e., agricultural productivity), and international trade (i.e., prevention of trade restrictions and distortions in world agricultural markets as in Target $2 b$ ). ISO Standards, however, are mainly developed for industry by industry (as per our discussion in Section 2.2). Therefore, ISO standards are most directly aligned with Targets 2.3 and 2.4 as both of these targets focus on industrial aspects (processes) to achieve zero hunger. For instance, ISO 22000 for food management systems is a standard that directly addresses the need for increased productivity and food safety. Likewise, the ISO 14001 standard for Environmental Management Systems implicitly addresses the need for sustainable agriculture. On the other hand, there are no standards that would directly address large scale societal targets, such as reducing prevalence of undernourishment. For this reason, we focus on Targets 2.3 and 2.4 (see Table 2 for further details). 
Table 2. SDG 2 Targets.

\begin{tabular}{|c|c|c|}
\hline SDG 2 Targets & Indicators & $\begin{array}{l}\text { Linkages between ISO } \\
\text { Standards and the SDG } 2 \text { Targets }\end{array}$ \\
\hline $\begin{array}{l}2.1 \text { By } 2030 \text {, end hunger and ensure access } \\
\text { by all people, in particular the poor and } \\
\text { people in vulnerable situations, including } \\
\text { infants, to safe, nutritious and sufficient } \\
\text { food all year round }\end{array}$ & $\begin{array}{l}\text { 2.1.1 Prevalence of undernourishment } \\
\text { 2.1.2 Prevalence of moderate or severe food } \\
\text { insecurity in the population, based on the } \\
\text { Food Insecurity Experience Scale (FIES) }\end{array}$ & $\begin{array}{l}\text { The linkage is indirect, no } \\
\text { standard directly addresses the } \\
\text { issues of undernourishment and } \\
\text { food insecurity }\end{array}$ \\
\hline $\begin{array}{l}2.2 \text { By } 2030 \text {, end all forms of malnutrition, } \\
\text { including achieving, by } 2025 \text {, } \\
\text { the internationally agreed targets on } \\
\text { stunting and wasting in children under } \\
5 \text { years of age, and address the nutritional } \\
\text { needs of adolescent girls, pregnant and } \\
\text { lactating women and older persons }\end{array}$ & $\begin{array}{l}\text { 2.2.1 Prevalence of stunting (height for age } \\
<-2 \text { standard deviation from the median of } \\
\text { the World Health Organization (WHO) } \\
\text { Child Growth Standards) among children } \\
\text { under } 5 \text { years of age } \\
\text { 2.2.2 Prevalence of malnutrition (weight for } \\
\text { height }>+2 \text { or }<-2 \text { standard deviation from } \\
\text { the median of the WHO Child Growth } \\
\text { Standards) among children under } 5 \text { years of } \\
\text { age, by type (wasting and overweight) }\end{array}$ & $\begin{array}{l}\text { The linkage is indirect, } \\
\text { no standard directly addresses the } \\
\text { issues of malnutrition }\end{array}$ \\
\hline $\begin{array}{l}2.3 \text { By 2030, double the agricultural } \\
\text { productivity and incomes of small-scale } \\
\text { food producers, in particular women, } \\
\text { indigenous peoples, family farmers, } \\
\text { pastoralists and fishers, including through } \\
\text { secure and equal access to land, other } \\
\text { productive resources and inputs, } \\
\text { knowledge, financial services, markets and } \\
\text { opportunities for value addition and } \\
\text { non-farm employment }\end{array}$ & $\begin{array}{l}\text { 2.3.1 Volume of production per labor unit } \\
\text { by classes of farming/pastoral/forestry } \\
\text { enterprise size } \\
\text { 2.3.2 Average income of small-scale food } \\
\text { producers, by sex and indigenous status }\end{array}$ & $\begin{array}{l}\text { Direct link, ISO standards address } \\
\text { agricultural productivity. } \\
\text { ISO standards do not directly } \\
\text { address income distribution in } \\
\text { agri value chains }\end{array}$ \\
\hline $\begin{array}{l}2.4 \text { By } 2020 \text {, ensure sustainable food } \\
\text { production systems and implement resilient } \\
\text { agricultural practices that increase } \\
\text { productivity and production, that help } \\
\text { maintain ecosystems, that strengthen } \\
\text { capacity for adaptation to climate change, } \\
\text { extreme weather, drought, flooding and } \\
\text { other disasters and that progressively } \\
\text { improve land and soil quality }\end{array}$ & $\begin{array}{l}\text { 2.4.1 Proportion of agricultural area under } \\
\text { productive and sustainable agriculture }\end{array}$ & $\begin{array}{l}\text { Direct link, ISO standards address } \\
\text { sustainability and agricultural } \\
\text { practices value chains }\end{array}$ \\
\hline $\begin{array}{l}2.5 \text { By } 2030 \text {, maintain the genetic diversity } \\
\text { of seeds, cultivated plants and farmed and } \\
\text { domesticated animals and their related wild } \\
\text { species, including through soundly } \\
\text { managed and diversified seed and plant } \\
\text { banks at the national, regional and } \\
\text { international levels, and promote access to } \\
\text { and fair and equitable sharing of benefits } \\
\text { arising from the utilization of genetic } \\
\text { resources and associated traditional } \\
\text { knowledge, as internationally agreed }\end{array}$ & $\begin{array}{l}\text { 2.5.1 Number of plant and animal genetic } \\
\text { resources for food and agriculture secured } \\
\text { in either medium or long-term conservation } \\
\text { facilities } \\
\text { 2.5.2 Proportion of local breeds classified as } \\
\text { being at risk, not-at-risk or at unknown } \\
\text { level of risk of extinction }\end{array}$ & $\begin{array}{l}\text { Indirect link, ISO standards do not } \\
\text { provide standards to maintain } \\
\text { genetic diversity }\end{array}$ \\
\hline
\end{tabular}

\section{Theoretical Background and Operationalization of the Study}

\subsection{Theoretical Perspectives in Standardization Research}

Academic research utilizes a broad set of theoretical perspectives to investigate various phenomena related to standards [30]. Based on the review of theoretical perspectives by Tuczek, Castka and Wakolbinger [30], the research is dominated by nine theoretical perspectives (Institutional Theory, The Resource Based View, Attitude Theory, Signaling Theory, Diffusion of Innovation Theory, Stakeholder Theory, Organizational Learning Theory, Transaction Cost Theory and High Reliability Theory). In our paper, we leverage two theoretical perspectives that are important in the context of this research-institutional and normative.

The institutional perspective is important in our research as a part of the discussion about the SDG goals focuses on the need for further institutionalization of the SDG agenda. Institutional Theory addresses the emergence, the mode of behaviour, and the collapse of institutions as a result of societal influence and explains why organizations converge and become similar [30-32]. The institutional 
perspective is often employed to determine drivers for adoption of standards or to determine the extent to which organizations embed standards in their daily routines [33]. The institutional perspective is also often leveraged in studies that explore ethical issues related to standardization [34] or the legitimacy of the standard development processes [35] — both issues that are highly relevant to the SDG agenda.

The normative perspective is also commonly used in research on standards. By definition, normativity refers to an evaluative standard by which a judgement is made about the outcome or the process. In the context of literature on standards, standards are seen as 'norms' or 'points of reference' for disparate users and stakeholders. ISO standards represent codified knowledge (that is agreed upon and accepted across the world); hence the standards provide common "reference points" for disparate users and stakeholders. In relation to the pursuit of the SDGs, both theoretical perspectives are important in determining the potential of ISO standards to contribute to the SDGs. The normative perspective is useful in assessing the potential of ISO standards (and ISO as an organization) to facilitate progress towards the SDGs by providing, modifying, or developing instruments (standards) to achieve the targets. For instance, the SDGs and their targets could require clarification and codification that could be achieved through the development of ISO standards. As Gil, Reidsma, Giller, Todman, Whitmore and van Ittersum [14] suggest, some SDG targets are not explicit enough and therefore could benefit from further fine-tuning through ISO Committees. From the institutional perspective, the quality infrastructure around ISO standards can provide a platform to monitor the use of standards for the benefit of the SDGs. The institutional perspective is therefore a useful perspective in determining the potential of ISO standards as being effective "agents of change". For instance, in some countries ISO standards are well embedded in national quality infrastructures, while in other countries this is to a lesser extent. Therefore, the level of the "quality" of quality infrastructure also affects the potential of ISO standards to address the SDGs. We leverage these perspectives further in other discussions later in the paper.

\subsection{Operalization of the Research Approach}

In general, standards related research is operationalized through the lenses of adoption, impact, and governance [11]. These perspectives essentially address the role and functioning of standards: development of standards, who adopts standards and why, the impact of standards-as measured by, for instance, financial performance [36] or health \& safety performance of adopting firms [37]—and issues related to governance-such as effectiveness of monitoring mechanisms [34]. Collectively, these perspectives provide an umbrella to investigate standards and this approach has been also adopted for conceptualization of this study.

Table 3 provides an overview of units of analysis used in this research and explains the research questions related to each unit of analysis. We determine and employ four units of analysis: ISOStandards Development, Adoption of ISO standards, Agricultural productivity of firms that adopt ISO standards, and Governance of ISO Standards. In determining these research units of analysis, we were guided by the objectives from SDG 2's targets. For instance, Target 2.3 focuses on agricultural production, which is linked to an 'impact' perspective as discussed above. Importantly though, instead of investigating the impact of standards in general (as previous literature often does), we investigate whether ISO standards specifically improve agricultural productivity. In other words, we study each research unit of analysis specifically in relation to the core issues of SDG 2. 
Table 3. Conceptualization of the study.

\begin{tabular}{ccc}
\hline Unit of Analysis & Research Question & Relation to the SDG 2/Rationale \\
\hline ISO Standards Development & $\begin{array}{c}\text { RQ 1: Do ISO standards provide a } \\
\text { platform to develop standards that } \\
\text { are aligned with SDG 2 targets? }\end{array}$ & $\begin{array}{c}\text { Advancement of the SDG 2 goals and } \\
\text { targets requires a mechanism to develop } \\
\text { standards that support their realization }\end{array}$ \\
\hline Adoption of ISO standards & $\begin{array}{c}\text { RQ 2: To what extent do } \\
\text { small-scale food producers adopt } \\
\text { ISO standards? Do they benefit } \\
\text { from the adoption? }\end{array}$ & $\begin{array}{c}\text { Small farms and wellbeing of local } \\
\text { communities and indigenous people is } \\
\text { central to Targets 2.3 and 2.4 }\end{array}$ \\
\hline $\begin{array}{c}\text { Agricultural productivity of firms } \\
\text { that adopt ISO standards }\end{array}$ & $\begin{array}{c}\text { RQ 3: Does adoption of ISO } \\
\text { Standards lead to improved } \\
\text { agricultural productivity? }\end{array}$ & $\begin{array}{c}\text { Improved agricultural productivity is } \\
\text { central to Target 2.3; especially by small } \\
\text { scale food producers }\end{array}$ \\
\hline Governance of ISO Standards & $\begin{array}{c}\text { RQ 4: Do the institutions } \\
\text { associated with monitoring of ISO } \\
\text { standards provide a platform for } \\
\text { institutionalization of SDG 2? }\end{array}$ & $\begin{array}{c}\text { Advancing the SDG 2 goals and targets } \\
\text { requires a mechanism to institutionalize } \\
\text { sustainable food production systems and } \\
\text { develop resilient agricultural practices }\end{array}$ \\
\hline
\end{tabular}

\subsection{Sample of Standards}

ISO has developed over 1600 standards for food [5]. In the recent report, ISO \& SDGs: Contributing to the UN Sustainable Development Goals with ISO standards [13], ISO singled out four standards of particular importance. On its website, as of 13 September 2020, ISO provides a list of a total of 77 standards that contribute to SDG 2 [38]. In our systematic literature search, we have included all these standards. As we report later, we found that the most papers are related to a narrow set of standards, with the greatest emphasis on ISO 22000, ISO 26000, and ISO 14001. The full list is provided in Appendix A.

\subsection{Search Procedure}

Our search procedure follows a standard approach used in systematic literature reviews: we defined the search protocol, retrieved the documents, determined criteria by which papers were included or excluded, and clarified the analytical processes by which the papers are reviewed $[39,40]$. The articles for this review were obtained from the ProQuest database-the largest multidisciplinary, full-text database available. We searched for peer reviewed articles in English-the search was conducted on 13 September 2020. In our search, we used a set of 77 ISO standards related to SDG 2. To obtain as many relevant articles as possible, we shortened the full names of standards; for instance, instead of searching for "ISO 34101-1:2019" or "ISO 34101-2:2019", the search was simplified as "ISO 34101". We have also recognized that some researchers refer to "ISO 14000", others to "ISO 14001". We have therefore used a string "ISO 1400*". The full search protocol is disclosed in Table 4, the search string "(All standards)" contains a list of all 77 standards (see Appendix A).

In line with Macpherson and Holt [40], we used a set of string searches that relate to our search sample. For each search sample, we used a set of 77 standards and a combination of key words (as disclosed in column 'Search String' in Table 4). The combination of keywords in the search string was determined based on the research questions as discussed in Table 3. For instance, in searching for "Agricultural productivity of firms that adopt ISO standards", we used a string (("productivity" OR "production" OR "income") AND ("food" OR "agribusiness")). The details are provided in Table 4. 
Table 4. Search Protocol.

\begin{tabular}{|c|c|c|c|c|c|}
\hline Search Sample & Objective & Scope & Search String & of Entries & of Relevant Entries \\
\hline $\begin{array}{l}\text { Scope of research } \\
\text { on ISO standards }\end{array}$ & $\begin{array}{l}\text { To provide descriptive } \\
\text { statistics about the } \\
\text { research studies }\end{array}$ & $\begin{array}{c}\text { Abstract, Scholarly } \\
\text { journals, Peer-reviewed, } \\
\text { English, search on Sep 13, } \\
\text { 2020; publication date 'all' }\end{array}$ & (All standards) & 949 & 949 \\
\hline $\begin{array}{l}\text { ISO Standards } \\
\text { Development }\end{array}$ & To address RQ1 & $\begin{array}{c}\text { Abstract, Scholarly } \\
\text { journals, Magazines, } \\
\text { Peer-reviewed, English, } \\
\text { search on Sep 13, 2020; } \\
\text { publication date 'all' }\end{array}$ & $\begin{array}{l}\text { (All standards) } \\
\text { ("standard } \\
\text { development" OR } \\
\text { "committee") }\end{array}$ & 17 & 15 \\
\hline $\begin{array}{l}\text { Adoption of ISO } \\
\text { standards }\end{array}$ & To address RQ2 & $\begin{array}{c}\text { Abstract, Scholarly } \\
\text { journals, Peer-reviewed, } \\
\text { English, search on Sep 13, } \\
\text { 2020; publication date 'all' }\end{array}$ & $\begin{array}{l}\text { (All standards) } \\
\text { AND ("adoption" } \\
\text { OR "benefits") } \\
\text { AND ("food" OR } \\
\text { "agribusiness")) }\end{array}$ & 14 & 12 \\
\hline $\begin{array}{c}\text { Governance of ISO } \\
\text { Standards }\end{array}$ & To address RQ4 & $\begin{array}{l}\text { Abstract, Scholarly } \\
\text { journals, Magazines, } \\
\text { Peer-reviewed, English, } \\
\text { search on Sep 13, 2020; } \\
\text { publication date 'all' }\end{array}$ & $\begin{array}{l}\text { (All standards) } \\
\text { AND } \\
\text { ("governance") }\end{array}$ & 8 & 7 \\
\hline
\end{tabular}

\subsection{Analytical Procedure}

The search procedure on all 77 standards yielded a total of 949 articles. This data set was used to determine which standards have been covered in the literature and no further analysis was performed. The in-depth analysis was conducted on a set of 47 articles that were identified in searches that addressed our research questions (as per Table 3). The analysis of each of those articles was guided by the research questions listed in Table 3. For instance, the analysis of articles on Agricultural productivity of firms that adopt ISO standards was guided by the research question "Does adoption of ISO Standards lead to improved agricultural productivity?" Whilst analyzing the articles, we collected notes on the evidence (such as whether the article reports favorable results, how productivity is measured, what are the limitations of the research, etc.) so that we could answer each research question. Similar processes were followed for all research questions.

\section{Findings}

The literature has lamented the lack of breadth of studies on ISO Standards [11]. Research often focuses on a relatively narrow set of standards, such as ISO 9001, ISO 14001, ISO 22000, and, more recently, ISO 26000. This has been also the case in our systematic literature review. Apart from these four widely covered standards, there are only 3 other standards in our set of 77 that are covered in the literature. Reini, et al. [41] focuses on the ISO 20400 standard for sustainable procurement and confirms the validity of the standard's elements, a point of shared agreement with Teixeira, et al. [42]. ISO 19869 Clean cookstoves and clean cooking solutions_Field testing methods for cookstoves is scrutinized by Arveson [43] as a framework to unravel "the tipping pot problem" of cooking safety (which causes injuries in developing countries). Ten studies use ISO 19152 Geographic information-Land Administration Domain Model (LADM) and demonstrate the normative value of this standard for creating on cadasters [44-47]. Next, we turn into the in-depth analysis of our research questions.

\subsection{ISO Standards Development}

The development of ISO Standards has long been overlooked in the literature. In part, the lack of studies was attributed to the lack of transparency of the standards development process $[15,48]$. 
However, the ISO standards development process became more transparent with the introduction of a multi-stakeholder standards development process-which was introduced as part of the development of the ISO 26000 standard for social responsibility [49]. During the development of ISO 26000, data, in the form of stakeholders' comments, was made publicly available. The dataset was used in the first academic studies on the ISO standards development process $[48,50]$. These studies, however, highlighted that the standards development process is biased towards industry stakeholders and towards participants that have experience with the standards development process. As a result, participants from developing countries tend to have less influence on the decision-making processes.

The literature search conducted in this study identified 15 articles related to the ISO standards development process. The literature demonstrates that ISO standards are widely recognized by industry and each revision is carefully scrutinized - especially within the community of quality practitioners [51]. ISO Standards are frequently set as reference points [52] and the credibility of the standards development process is often legitimized by the robust committee structure [53]. The standards development process is also coordinated between committees. This coordination results in opportunities for integration of various standards, which can benefit end users [54]. For example, the integration of ISO standards has been discussed in the context of ISO 14001 and ISO 9001 [55], as well as in relation to the Sarbanes-Oxley Act [56]. The articles also demonstrate that the committee processes facilitate continuous improvement of existing standards [57] and that the revision process is publicly debated [58].

Although the literature provides some insight into ISO standards development, the effectiveness of both the standard development process and the involvement of underrepresented stakeholders is rarely addressed. Apart from the above-mentioned studies into the development of ISO 26000 [48,50], most of the other literature provides a process-oriented analysis of the ISO standards development process. The literature does not cover ISO Standards development related specifically to food (i.e., ISO 22000) and agribusiness (i.e., development of standards on sustainability and resilience). There is also a lack of research related to issues of malnutrition and how the ISO standards development processes might serve to address malnutrition and matters related to SDG 2 Targets 2.1 and 2.2. Despite these shortcomings in empirical evidence about the standards development process, the capabilities to develop standards and the infrastructure that is already in place could provide valuable to the SDG agenda. We conclude that:

Proposition 1. The ISO standards development processes is well established and could provide a platform to develop new standards to achieve the SDG 2 targets.

\subsection{Adoption of ISO Standards}

Adoption of ISO standards has been widely covered in the literature [11]. Broadly, the literature focuses on adoption at the firm level (e.g., reasons for adoption), as well as at the macro level (e.g., why and how standards diffuse). Adoption of standards in the context of SDG 2 is particularly important in the context of Target 2.4. Target 2.4 aims to achieve adoption of 'sustainability' and 'resilient' practices. As part of Target 2.4, the emphasis is particularly put on adoption of irrigation systems and on fertilizer use, even though this emphasis is questioned by some as quite narrow [14]. Another important question is about the adoption of ISO standards amongst small scale producers.

We found 12 papers that cover various aspects of implementation in the context of the food and agribusiness sectors. In general, the most emphasis is placed on ISO 22000 and many studies concluded that adoption is more challenging and less likely in small companies $[59,60]$. Small scale producers are in general less likely to seek ISO certification, which is in part attributed to 'organisational readiness' of small producers [59,61], cost [59,62], and lack of knowledge [62]. However, studies also show that even in the context of small scale producers, ISO standards can serve as a springboard of adoption of multiple productivity enhancing principles—such as lean or requirements of multiple standards [63]. Adoption is driven by external (i.e., pressure from customers) and internal motives (i.e., seeking improvements in operations), and these motives often overlap [64]. Escanciano and Santos-Vijande [65] 
assert that ISO 22000 is used across the value chain and point out that the reasons for adoption do not significantly differ between small and large firms. Massoud, et al. [66] assert that food companies are more concerned with adoption of food safety rather than sustainability practices. Few companies in Africa (except for those that are large and focused on exports) have adopted ISO 22000 [67].

The literature underlines the global adoption of ISO standards whilst pointing out the difficulties for adoption of ISO standards for small scale producers. The research, however, tends to be grounded in the context of food firms and provides far less insight into entire agribusiness value chains. The studies do not address the matters that are central to SDG 2, such as adoption of sustainability and resilience practices. We conclude that:

Proposition 2. ISO standards are less adopted by small scale producers and in developing countries; adoption of standards (at the moment) amongst these groups limits the potential of ISO standards to contribute to the SDG agenda.

\subsection{Agricultural Productivity of Firms that Adopt ISO Standards}

The impact of ISO standards is widely researched. Previous studies have investigated the impact in terms of financial performance, operational performance, and numerous other performance indicators [11]. Even though there is discrepancy of findings across the measures and across the individual studies, on balance, the results suggest a positive impact of standards [7,11].

Agricultural productivity is key to Target 2.3. In general, productivity is defined as a ratio of outputs to inputs. In the agricultural context, output is usually measured by the market value of the produce, while the input can be measured by, for instance, in terms of labor or land (crop yield) [14]. We have identified 13 papers that broadly address this topic. The papers are mostly focused on the impact of ISO 22000 on food production systems [64,65,67-69] and investigate the processing and distribution of food rather than focusing on agricultural processes. ISO 22000 is reported to positively affect the implementation of codified processes [68]. It is also reported to provide a platform for implementation of other key processes in food production-such as critical control points [70] or Hazard Analysis and Critical Control Point (HACCP) [71]—and also in providing conceptual guidance (i.e., decision trees that are specified in the standard) [70]. In these papers, the authors point at the indirect impact of ISO standards on productivity in food systems. The direct impact is determined by relatively few studies. Zimon, Madzik and Domingues [68] point out that ISO 22000 leads to improvements in food quality and waste minimization. This point is also made by Escanciano and Santos-Vijande [65], who attribute improvements in efficiency and food safety to ISO 22000 as well. Based on a review of the literature, Panghal, Chhikara, Sindhu and Jaglan [69] conclude that "ISO 22000 along with its sister standards are auditable, reliable, and reasonable to ensure safe production, distribution, and consumption of food." Salim, Padfield, Chew, Syayuti, Papargyropoulou and Mun Hou [62] assert that the standards have a greater positive impact on larger firms, as smaller firms benefit less due to high implementation cost and lack of knowledge about the requirements of the standards. Păunescu, Argatu and Lungu [64] propose that the main impact is in terms of provision of safer products by reduction of illnesses and other risks. Kussaga, Jacxsens, Tiisekwa and Luning [67] attribute, in part, food contamination in African food-processing firms to low uptake of ISO 22000 and HACCP.

It is notable that none of the papers reviewed provides a clear-cut analysis of agricultural productivity. The studies show improvement in food safety and productivity (i.e., ISO 22000). However, SDG targets are more specific (i.e., preparedness for climate change; progressive improvement of land and soil quality, etc.). Studies that would determine, for instance, the impact of ISO standards on land yield, are missing. There is also a lack of studies that would shed light on the impact of ISO standards on income of small-scale producers. It is also unclear if (and how) ISO standards can address the need to "double the agricultural productivity" (as per Target 2.3) as well as if (and how) ISO standards guide firms toward improved capabilities to adapt to climate change or other sustainability performance 
related aspects. Target 2.4 is focused on the development and implementation of food production systems, which not only increase productivity, but also strengthen the capabilities of the food sector to adapt to climate change and improve land and soil quality. We therefore propose the following:

Proposition 3. ISO standards can contribute to improved productivity of adopting firms and therefore have the potential to address SDG 2.

\subsection{Governance of ISO Standards}

Broadly speaking, governance of standards refers to control mechanisms that ensure consistent adoption and monitoring of standards across the world [72]. Governance of ISO standards is ensured by the network of accreditation bodies, certification bodies, and auditors that form an essential part of quality infrastructure across the globe. The development of this infrastructure started after World War II, but the governance of ISO standards has been scarcely covered in the literature [73]. While an increasing number of papers has recently appeared, these studies tend to concentrate on quality or environmental standards rather than standards related to food.

Our search identified 7 papers that discuss the governance of ISO standards in the context of food standards. Panghal, Chhikara, Sindhu and Jaglan [69] argue that the ISO 22000 standard for food management systems provides a framework for an "internationally harmonized system." Particularly notable is the incorporation of critical hazard points in this standard, which is also an essential element of other standards as well as domestic regulations, and a presence of a global network of conformity assessment services. Both of these elements ensure that food safety and food quality is consistent across the globe. Though ISO 22000 certified firms often show fewer non-conformities in comparison to other non-ISO based standards [74], ISO 22000 audits also report an alarming number of non-conformities-especially in the meat industry and in small companies [74].

Overall, the studies reviewed provide limited insight into the governance of ISO standards and its effectiveness. In particular, there is a lack of understanding of the effectiveness of quality infrastructure related to standards addressing SDG 2 and its effectiveness in developing countries. Furthermore, fraud, conflict of interest, inconsistencies in audits and other ethical issues can sometimes compromise ISO standards' governance and may result in problematic outcomes, such as certification of substandard firms. However, these widely acknowledged issues should not alone discourage the use of ISO standards as a platform for implementing SDG 2 [34]. After all, the infrastructure behind the governance (i.e., accreditation and certification) provides an important foundation on which to build implementation of the SDG agenda. Finally, small scale producers and indigenous communities also need more attention in the broader question of effectiveness of governance. The governance mechanisms that might be more suitable to larger firms and follow technocratic approaches need to be modified and changed, such as less complex requirements and recognition of unique practices amongst indigenous communities [75]. Notwithstanding those issues, we propose the following:

Proposition 4. The ISO infrastructure of certification bodies, accreditation bodies, and auditors provides a potential platform to institutionalize the SDG agenda.

\section{Discussion}

Understanding the role of ISO standards in terms of standards development, adoption, impact of agricultural productivity, and governance of standards is important in determining the role of ISO standards in the pursuit of the SDG agenda. The systematic review on this topic revealed that, on the one hand, ISO standards provide a global platform to develop standards and to enforce (monitor) processes and performance of firms and industries. On the other hand, the paper also revealed that standards development is industry-centric and that the adoption, impact, and governance patterns are inconsistent. Furthermore, the SDGs and its associated targets are very broad-some targets are associated with improved firm performance, others are very generic (e.g., ending hunger as per 
Target 2.1). Given the industry-based nature of ISO standards, targets related to improved firm-level performance are a clear match with existing ISO standards. For instance, Targets 2.3 and 2.4 are clearly aligned with the content of the most important standards, such as ISO 22000 or ISO 14001. On the other hand, Target 2.1, for instance, "end hunger and ensure access by all people, in particular the poor and people in vulnerable situations, including infants, to safe, nutritious and sufficient food all year round" is probably more suited for a policy-based discussion that extends well beyond the industry focused standardization that ISO standards currently provide. The main findings and research gaps from the literature are presented in Table 5.

Table 5. Summary of Research Findings.

\begin{tabular}{|c|c|c|c|}
\hline Research Unit of Analysis & Findings & Research Gaps & Propositions \\
\hline $\begin{array}{l}\text { ISO Standards } \\
\text { Development }\end{array}$ & $\begin{array}{l}\text { Standards Committees operate } \\
\text { based on clearly defined processes } \\
\text { and based on the expertise and } \\
\text { consensus of nominated experts } \\
\text { Standards committees are } \\
\text { dominated by industry with } \\
\text { relatively low levels of } \\
\text { involvement of other stakeholders }\end{array}$ & $\begin{array}{l}\text { Lack of research of the effectiveness of } \\
\text { standards development processes of } \\
\text { standards that are central to the pursuit } \\
\text { of SDG } 2 \text { and its targets (as per the list } \\
\text { Appendix A) } \\
\text { Lack of research on the inclusion and } \\
\text { influence of underrepresented } \\
\text { stakeholders as well as developing } \\
\text { countries that are most affected by } \\
\text { malnourishment or low levels of } \\
\text { agricultural productivity }\end{array}$ & $\begin{array}{l}\text { The standards } \\
\text { development processes } \\
\text { are well established and } \\
\text { could provide a platform } \\
\text { to develop new } \\
\text { standards to achieve the } \\
\text { SDG } 2 \text { targets. }\end{array}$ \\
\hline Adoption of ISO standards & $\begin{array}{l}\text { Global uptake of ISO standards } \\
\text { yet low adoption in developing } \\
\text { countries } \\
\text { Small firms find adoption difficult } \\
\text { and burdensome }\end{array}$ & $\begin{array}{l}\text { Lack of research on factors that mediate } \\
\text { the adoption of ISO standards in small } \\
\text { farms and agribusinesses } \\
\text { Lack of research on adoption of } \\
\text { sustainability and resilient practices and } \\
\text { how ISO standards enable adoption of } \\
\text { sustainable practices (Target 2.4) } \\
\text { Lack of research on the role of ISO } \\
\text { standards on adoption of practices that } \\
\text { enable maintaining of genetic diversity, } \\
\text { plant banks and other targets } \\
\text { (Target 2.5) }\end{array}$ & $\begin{array}{l}\text { ISO standards are less } \\
\text { adopted by small firms, } \\
\text { and in developing } \\
\text { countries, adoption of } \\
\text { standards (at the } \\
\text { moment) amongst these } \\
\text { groups limits the } \\
\text { potential of ISO } \\
\text { standards to contribute } \\
\text { to the SDG agenda }\end{array}$ \\
\hline $\begin{array}{l}\text { Agricultural productivity } \\
\text { of firms that adopt } \\
\text { ISO standards }\end{array}$ & $\begin{array}{l}\text { The research suggests (on average) } \\
\text { that there is improved } \\
\text { productivity }\end{array}$ & $\begin{array}{l}\text { Lack of research that addresses the role } \\
\text { of ISO standards in improving } \\
\text { agricultural productivity specifically } \\
\text { Lack of evidence on the impact of } \\
\text { standards on average income of } \\
\text { small-scale producers }\end{array}$ & $\begin{array}{l}\text { ISO standards can } \\
\text { contribute to improved } \\
\text { productivity of adopting } \\
\text { firms and therefore have } \\
\text { the potential to address } \\
\text { SDG } 2\end{array}$ \\
\hline
\end{tabular}

At the outset of the paper, we anchored our analytical approach in normative and institutional perspectives. Throughout the analysis, we have demonstrated how these two perspectives assist in understanding of the potential of ISO standards to address the SDGs. The normative perspective is in particular important in the discussion on the targets. The ongoing discussion on whether the targets are conceptually clear, quantifiable, and universally relevant suggests that the normative development of the SDGs is still being challenged [14]. Such discussion is, however, similarly challenging in the domain of ISO standards [73], as well as other policy setting environments, such as crime prevention standards [76]. In the context of ISO Management System Standards, for instance, standards determine key elements of 'a system' and often lack the concept of 'targets' altogether. On the one hand, such an approach could be seen as innovative: lack of particular targets (and focus on elements of a system) allows for a general applicability and the setting of context specific norms [77]. On the other hand, 
lack of specific targets also allows for free-riding and using standards for legitimizing purposes. Clearly, the normative processes behind the setting of targets and standards are far from conclusive and will be subject of further discussions. The institutional perspective is important for explaining the processes that lead to the institutionalization of the principles of the SDG agenda and in embedding the changes necessary for achieving SDG goals. Similarly, the parallels between ISO standards and the SDG agenda are striking. In both cases, the institutionalization processes are complex and challenging at several levels. For instance, institutionalization of a standard and/or a policy is accompanied by its 'translation' or 'interpretation' [11,76], which often leads to modifications and variations [78]. Such variation is also observable in the monitoring of standards and targets $[79,80]$ even with the improvements in monitoring approaches and technologies such as Big Data [81].

Given the abovementioned challenges and uncertainties, there are numerous avenues for future research on the role of ISO Standards in the pursuit of SDG 2 and the other SDGs. First, the research needs to explore the role of ISO standards in the pursuit of the SDGs at three levels: global, national, and industry. The studies can consider for instance, how various stakeholders (individually or in partnerships) use ISO standards to drive, institutionalize, and report on the SDG agenda. Limited evidence suggests that ISO standards already play a role in reporting on SDG progress [82], yet more focused work is needed in this area, especially in distilling the role of ISO standards in the institutionalization of the SDG agenda. Second, there is need to focus on the role of ISO standards in achieving specific SDG targets.

For instance, target 2.4 aims to enhance the adoption of sustainable and resilient agricultural practices. Future research might scrutinize the role of ISO standards in achieving this target, as well as others, while also considering contextual factors, such as achieving the targets in different industries and in developing countries. Achieving SDG 2 requires policy coherence and respect for the rights, needs, and demands of vulnerable groups-which might be problematic in authoritarian regimes and countries with a long history of famines, high levels of malnutrition, and vulnerable domestic economies [1] —also an area for future research. Future research should also explore contingencies such as underdeveloped quality infrastructure and its impact on the influence and effectiveness of ISO standards in advancing the SDG agenda. An overarching question guiding such research could be: To what extent should the role of ISO standards differ in different contexts? This might lead to questions such as: How should the quality infrastructure be developed so as to further support the SDGs and their associated targets? It is also important to acknowledge that achieving any SDG targets would not be the role of ISO standards alone. More informed discussion and empirical evidence is needed on the role of multiple standards and multiple stakeholders in achieving the SDGs and their targets.

Third, future research could study gaps in existing standards, and the extent to which such gaps could be addressed through modification of existing standards and/or the development of new standards. A key question in the modification or development of any standard will be where and how stakeholders should be involved in those processes. The expected performance to be achieved through the implementation of any standard will also need to be considered. For example, research might explore whether ISO standards can assist in the achievement of performance-based outcomes, such as ensuring incomes of small-scale food producers? Standards for nutrition and malnutrition might also need further revision to support SDG 2, particularly since it assumes an increased attention to healthy and sustainable diets. Most countries face some form of malnutrition and sub-optimal diets, which are a major cause of various forms of hunger [1] —researchers might explore if ISO standards are best positioned to address such issues? Finally, technology plays an increasingly important role in everyday life (e.g., Internet of Things) and industrial development [83]. Technologies are also increasingly important in facilitating standardization and certification [84,85]. For instance, blockchain innovations are used to increase data security and transparency to facilitate many difficult aspects of (international) law enforcement, which in turn, support international climate finance transfers [86]. Researchers might 
explore how such technologies can enhance the effectiveness of ISO standards and the pursuit of the SDG agenda, as well as investigating the use of Big Data in reporting on the SDG targets [81].

\section{Conclusions}

ISO standards are globally adopted standards that significantly influence international business. ISO standards therefore could play a significant role in achieving the SDGs. In this paper, we have discussed the role of ISO standards in relation to SDG 2 in terms of ISO standard development, adoption of ISO standards, agricultural productivity, and governance. We have also discussed gaps in the research to encourage the research agenda on understanding of the role of ISO standards in the pursuit of UN SDGs.

The paper highlights a great potential for ISO standards to play a significant role in pursuing the SDG agenda. Yet for that potential to materialize, some key aspects of ISO standards and the ISO infrastructure need to be modified to fit the SDG agenda or need to be combined with other institutional mechanisms. The ISO standards development process, for instance, is industry dominated and lacks consultation and stakeholder mobilization beyond the existing committees and beyond existing participating institutions [48]. If ISO standards are to play a more significant part of the UN SDG agenda, this issue would need to be addressed. Lack of transparency and lack of inclusiveness are, of course, non-congruent with the spirit of the SDG agenda. At the same time, it might be unrealistic to expect that the ISO standards development processes can be changed and perhaps, other mechanisms (outside of ISO) can be used to provide wider stakeholder platforms for a dialogue.

Our research also has implications for practice and for any stakeholders that are involved in the SDG agenda, being individual firms, industry consortia, policy makers, or NGOs. All of these stakeholders can build on the interlinkages of ISO standards and the SDGs discussed in this paper. The paper explains the role of ISO Standards and clearly demonstrates the importance of these standards in industrial processes (locally and in international trade). This is particularly important for policy makers that are drafting policies which aim to meet the SDG goals and targets. Policy makers might find ways to encourage the use of ISO standards to enhance collaboration in global supply chains and bring small producers (especially from developing countries) into those supply chains. As we discuss in Sections 4 and 5, however, such policies need to consider the limitations of ISO standards and be accompanied by investments that help small producers adopt the requirements of the standards. The existing infrastructure of auditors, certifiers, and accreditors can also play a role in reporting progress towards the SDG goals and targets, though it is clear that further development to align such infrastructure needs to be explored. Finally, we would also like to encourage the main actors (i.e., the UN and ISO) to fund future research in the areas outlined in this paper.

The main contribution of this paper is in providing an analytical approach to determine the potential of ISO standards to address SDG 2. The key limitation of our work is that we have not addressed the full spectrum of standards for all SDGs. We have also limited our research to standards developed by ISO, though we acknowledge a combination of standards from other standards developers could further deepen the analysis. At the same time, we envisage that a similar approach can be used to address the role of ISO standards (or standards from other developers) for the entire SDG agenda. We have also listed a number of research questions that are needed to further shift our understanding of the linkages between ISO standards and the SDGs. These questions are broadly linked to the main units of research analysis (Table 5). Most importantly, we call for future research at the global, national, and industry levels, which is dearly needed to form more nuanced approaches for embedding ISO standards to the SDGs.

Author Contributions: Conceptualization, methodological approach and writing X.Z., P.C. and C.S., data collection and literature review analysis X.Z. and P.C. All authors have read and agreed to the published version of the manuscript.

Funding: This research received no external funding. 
Conflicts of Interest: X.Z. and C.S. declare no conflict of interest. P.C. served or has been serving on several ISO committees however he has no conflict of interest.

\section{Appendix A}

Table A1. List of ISO Standards Related to SDG 2.

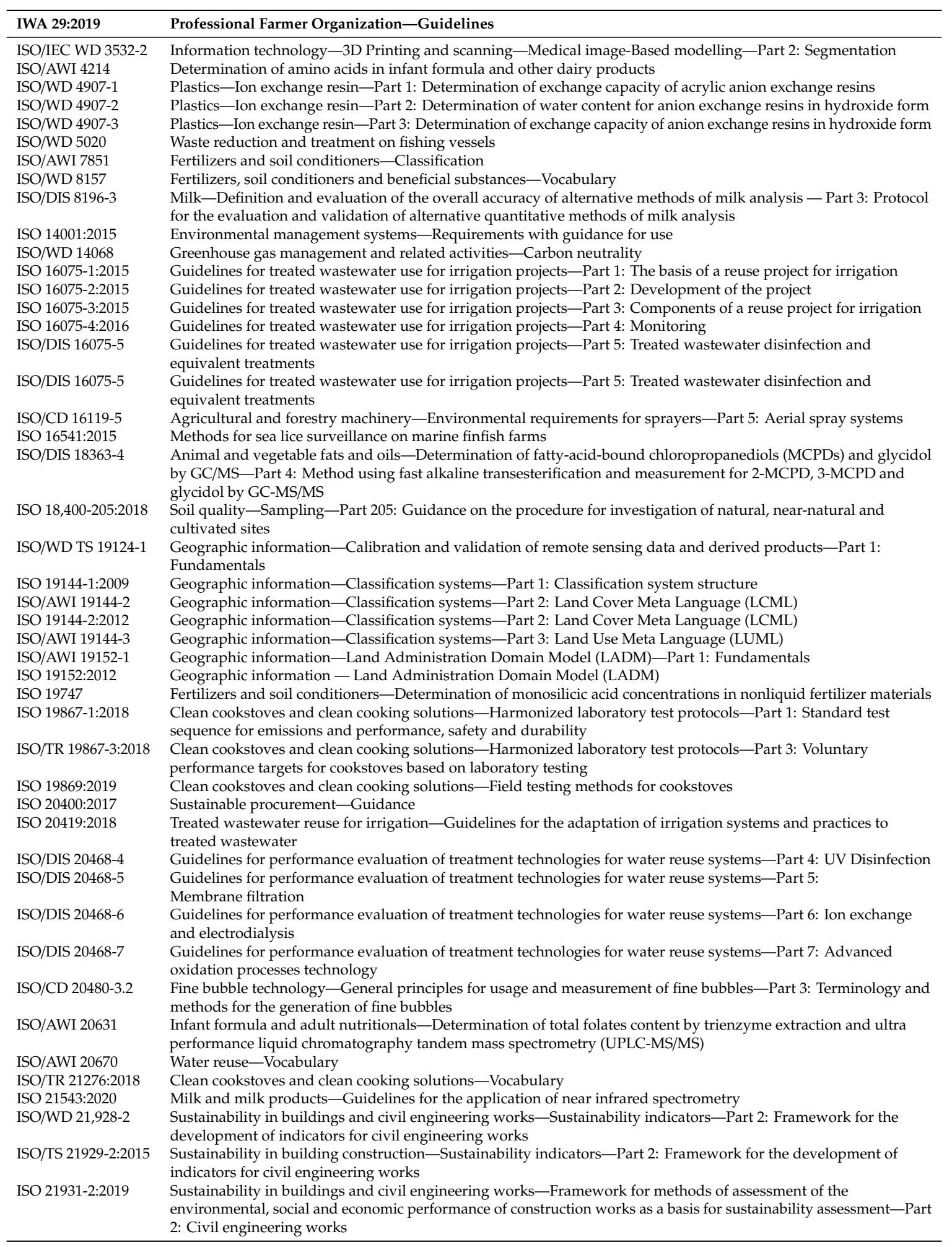


Table A1. Cont.

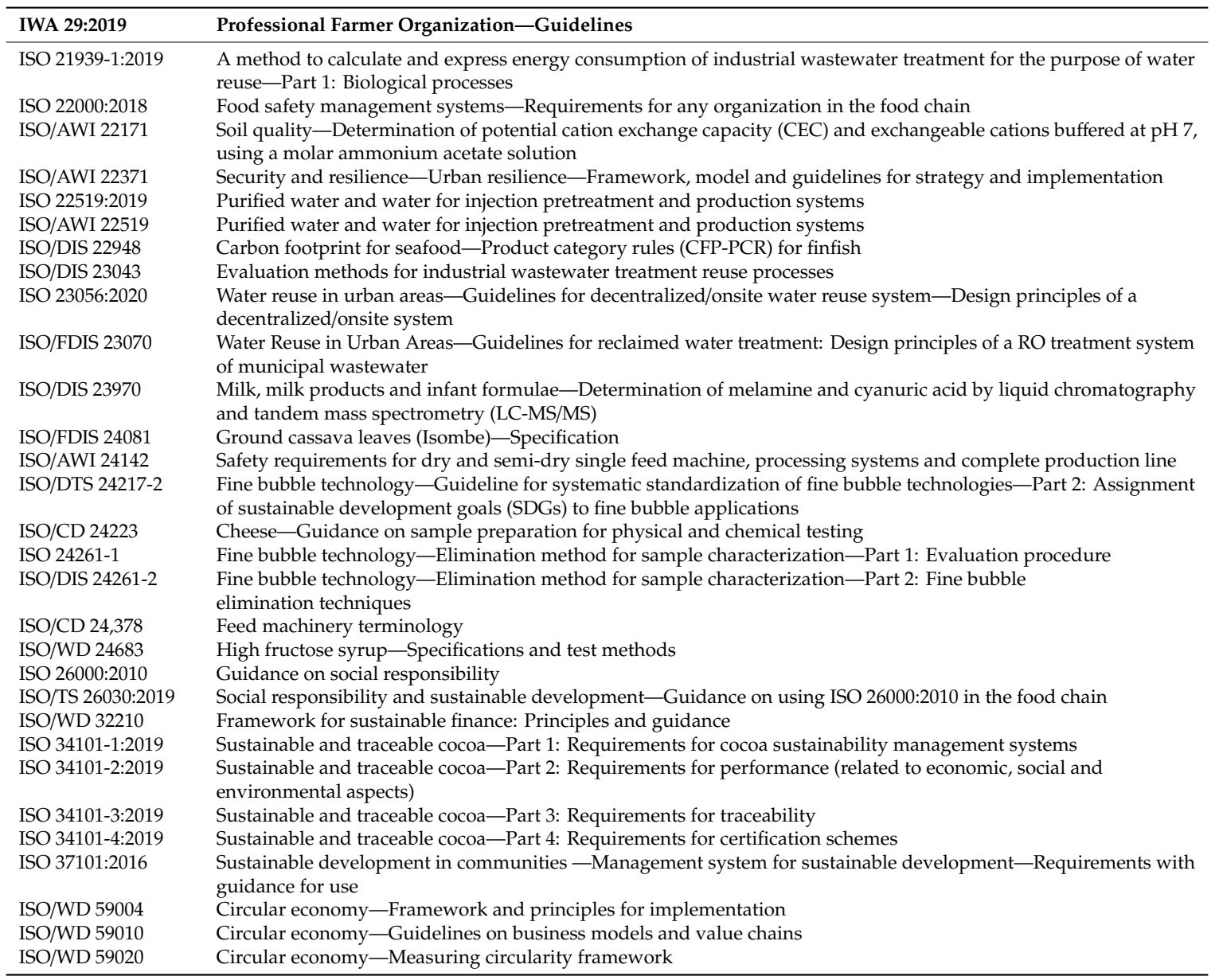

\section{References}

1. Banik, D. Achieving Food Security in a Sustainable Development Era. Food Ethics 2019, 4, 117-121. [CrossRef]

2. Engebretsen, E.; Heggen, K.; Ottersen, O.P. The Sustainable Development Goals: Ambiguities of accountability. Lancet 2017, 389, 365. [CrossRef]

3. UN World 'Not Keeping Pace' in Implementing Sustainable Development Goals, Secretary-General Stresses, as Development Financing Forum Begins. Available online: https://www.un.org/press/en/2019/ecosoc6972. doc.htm (accessed on 1 November 2020).

4. Jabbari, M.; Motlagh, M.S.; Ashrafi, K.; Abdoli, G. Differentiating countries based on the sustainable development proximities using the SDG indicators. Environ. Dev. Sustain. 2019, 1-19. [CrossRef]

5. ISO. ISO and Food; International Organization for Standardization: Geneve, Switzerland, 2018.

6. Blind, K.; Mangelsdorf, A.; Niebel, C.; Ramel, F. Standards in the global value chains of the European Single Market. Rev. Int. Political Econ. 2018, 25, 28-48. [CrossRef]

7. Swann, G.M.P. The Economics of Standardization: An Update; Innovative Economics Limited: Nottingham, UK, 2010.

8. ISO Benefits of Standards. Available online: https://www.iso.org/benefits-of-standards.html (accessed on 1 November 2020).

9. Bartram, R. Driving into a Cleaner Future. ISO Focus 2019, 134, 6-13.

10. ISO-Survey. The ISO Survey of Management Systems Standards Certifications (2017) EXPLANATORY NOTE. Available online: https://isotc.iso.org/livelink/livelink/fetch/-8853493/8853511/8853520/18808772/00._Overall_ results_and_explanatory_note_on_2017_Survey_results.pdf?nodeid=19208898\&vernum=-2 (accessed on 28 June 2018).

11. Castka, P.; Corbett, C.J. Management Systems Standards. Diffusion, Impact and Governance of ISO 9000 , ISO 14000, and Other Management Systems Standards. Found. Trends Technol. Oper. Manag. 2015, 7, 233. 
12. FAO. Agriculture: Key to Achieving the 2030 Agenda for Sustainable Development; Food and Agriculture Organization of the United Nations: Rome, Italy, 2016.

13. ISO. ISOESDG: Contributing to the UN Sustainable Development Goals with ISO Standards; International Organization for Standardization: Geneva, Switzerland, 2020.

14. Gil, J.D.B.; Reidsma, P.; Giller, K.; Todman, L.; Whitmore, A.; van Ittersum, M. Sustainable development goal 2: Improved targets and indicators for agriculture and food security. Ambio 2019, 48, 685-698. [CrossRef]

15. Castka, P.; Balzarova, M.A. The impact of ISO 9000 and ISO 14000 on standardisation of social responsibility-An inside perspective. Int. J. Prod. Econ. 2008, 113, 74-87. [CrossRef]

16. Blind, K.; Mangelsdorf, A.; Pohlisch, J. The effects of cooperation in accreditation on international trade: Empirical evidence on ISO 9000 certifications. Int. J. Prod. Econ. 2018, 198, 50-59. [CrossRef]

17. UNIDO. Quality \& Standards and Their Role in Responding to COVID-19; United Nations Industrial Development Organization: Vienna, Austria, 2020.

18. UNIDO. Advancing Conformity Assessment for the New Digital Age; UNIDO, Department of Digitalization, Technology and Innovation (DTI): Vienna, Austria, 2020.

19. Brunsson, N.; Jacobsson, B. (Eds.) The Contemporary Expansion of Standardization. In A World of Standards; Oxford University Press: Oxford, UK, 2000; pp. 1-17.

20. ISO. ISO and Food; International Organization for Standardization: Geneve, Switzerland, 2017.

21. Robert, K.W.; Parris, T.M.; Leiserowitz, A.A. What is Sustainable Development? Goals, Indicators, Values, and Practice. Environ. Sci. Policy Sustain. Dev. 2005, 47, 8-21. [CrossRef]

22. Chasek, P.S.; Wagner, L.M.; Leone, F.; Lebada, A.M.; Risse, N. Getting to 2030: Negotiating the post-2015 sustainable development agenda. Rev. Eur. Comp. Int. Environ. Law 2016, 25, 5-14. [CrossRef]

23. Quental, N.; Lourenco, J.M.; Da Silva, F.N. Sustainable development policy: Goals, targets and political cycles. Sustain. Dev. 2011, 19, 15-29. [CrossRef]

24. WCED (World Commission on Environment and Development). Our Common Future; Oxford University Press: Oxford, UK, 1987; Volume 17, pp. 1-91.

25. Griggs, D.; Stafford-Smith, M.; Gaffney, O.; Rockström, J.; Öhman, M.C.; Shyamsundar, P.; Steffen, W.; Glaser, G.; Kanie, N.; Noble, I. Sustainable development goals for people and planet. Nature 2013, 495, 305-307. [CrossRef] [PubMed]

26. Biermann, F.; Kanie, N.; Kim, R.E. Global governance by goal-setting: The novel approach of the UN Sustainable Development Goals. Curr. Opin. Environ. Sustain. 2017, 26-27, 26-31. [CrossRef]

27. Banik, D. Achieving Food Security in a Sustainable Development Era; Springer: Berlin/Heidelberg, Germany, 2020.

28. Leal Filho, W.; Brandli, L.L.; Lange Salvia, A.; Rayman-Bacchus, L.; Platje, J. COVID-19 and the UN sustainable development goals: Threat to solidarity or an opportunity? Sustainability 2020, 12, 5343. [CrossRef]

29. UN. Progress towards the Sustainable Development Goals. Report of the Secretary-General; United Nations, Economic and Social Council: New York, NY, USA, 2020.

30. Grocke, M.U.; Light, T.; Collado, E.K. Using Microlending to Achieve SDG 2: A Qualitative Exploration of the Nutrition-Related Impacts of Microlending Participation in Manila, Philippines. J. Sustain. Res. 2020, 2, 1-23.

31. Veldhuizen, L.J.L.; Giller, K.E.; Oosterveer, P.; Brouwer, I.D.; Janssen, S.; van Zanten, H.H.E.; Slingerland, M.A. The Missing Middle: Connected action on agriculture and nutrition across global, national and local levels to achieve Sustainable Development Goal 2. Glob. Food Secur. 2020, 24, 100336. [CrossRef]

32. UN Goal 2: Zero Hunger. Available online: https://www.un.org/sustainabledevelopment/hunger/ (accessed on 31 October 2020).

33. Tuczek, F.; Castka, P.; Wakolbinger, T. A review of management theories in the context of quality, environmental and social responsibility voluntary standards. J. Clean. Product. 2018, 176, 399-416. [CrossRef]

34. Meyer, J.W.; Rowan, B. Institutionalized Organizations: Formal Structure as Myth and Ceremony. Am. J. Soc. 1977, 83, 340-363. [CrossRef]

35. DiMaggio, P.; Powell, W. The iron cage revisited: Institutional isomorphism and collective rationality in organizational fields. Am. Soc. Rev. 1983, 48, 147-160. [CrossRef]

36. Sandholtz, K.W. Making Standards Stick: A Theory of Coupled vs. Decoupled Compliance. Organ. Stud. 2012, 33, 655-679. [CrossRef]

37. Prajogo, D.; Castka, P.; Searcy, C. Paymasters and Assurance Providers: Exploring Firms' Discretion in Selecting Non-financial Auditors. J. Bus. Ethics 2020, 1-17. [CrossRef] 
38. Mueller, M.; dos Santos, V.G.; Seuring, S. The Contribution of Environmental and Social Standards towards Ensuring Legitimacy in Supply Chain Governance. J. Bus. Ethics 2009, 89, 509-523. [CrossRef]

39. Corbett, C.J.; Montes-Sancho, M.J.; Kirsch, D.A. The financial impact of ISO 9000 certification in the United States: An empirical analysis. Manag. Sci. 2005, 51, 1046-1059. [CrossRef]

40. Naveh, E.; Marcus, A. Financial performance, ISO 9000 standard and safe driving practices effects on accident rate in the US motor carrier industry. Accid. Anal. Prev. 2007, 39, 731-742. [CrossRef] [PubMed]

41. Tian, M.; Deng, P.; Zhang, Y.; Salmador, M.P. How does culture influence innovation? A systematic literature review. Manag. Decis. 2018, 56, 1088-1107. [CrossRef]

42. Macpherson, A.; Holt, R. Knowledge, learning and small firm growth: A systematic review of the evidence. Res. Policy 2007, 36, 172-192. [CrossRef]

43. Reini, W.; Abduh, M.; Messah, Y. Framework for Sustainable Procurement-Identifying Elements for Construction Works. Appl. Mech. Mater. 2020, 897, 245-249.

44. Teixeira, C.R.B.; Assumpção, A.L.; Correa, A.L.; Savi, A.F.; Prates, G.A. The Contribution of Green Logistics and Sustainable Purchasing for Green Supply Chain Management. Indep. J. Manag. Prod. 2018, 9, 1002-1026. [CrossRef]

45. Arveson, P.T. The Tipping Pot Problem. Wash. Acad. Sci. J. Wash. Acad. Sci. 2018, 104, 29-38.

46. Janečka, K.; Souček, P. A Country Profile of the Czech Republic Based on an LADM for the Development of a 3D Cadastre. ISPRS Int. J. Geo-Inf. 2017, 6, 143. [CrossRef]

47. Pouliot, J.; Vasseur, M.; Boubehrezh, A. How the ISO 19152 Land Administration Domain Model performs in the comparison of cadastral systems: A case study of condominium/co-ownership in Quebec (Canada) and Alsace Moselle (France). Comp. Environ. Urban Syst. 2013, 40, 68-78. [CrossRef]

48. Stoter, J.; Ploeger, H.; van Oosterom, P. 3D cadastre in the Netherlands: Developments and international applicability. Comp. Environ. Urban Syst. 2013, 40, 56-67. [CrossRef]

49. Vučić, N.; Mađer, M.; Roić, M.; Vranić, S. Towards a Croatian 3D Cadastre Based on the Ladm. ISPRS Ann. Photogramm. Remote Sens. Spat Inf. Sci. 2017, IV-4/W4, 399-409.

50. Helms, W.S.; Oliver, C.; Webb, K. Antecedents of Settlement on a New Institutional Practice: Negoations of the ISO 26000 Standard on Social Responsibility. Acad. Manag. J. 2012, 55, 1120-1145. [CrossRef]

51. Bowers, D. Making social responsibility the standard. Qual. Prog. 2006, 39, 35-38.

52. Balzarova, M.A.; Castka, P. Stakeholders' Influence and Contribution to Social Standards Development: The Case of Multiple Stakeholder Approach to ISO 26000 Development. J. Bus. Ethics 2012, 111, 265-279. [CrossRef]

53. Liebesman, S. Work in Progress. Qual. Prog. 2013, 52-53.

54. Block, M.R. The White House manages green. Qual. Prog. 2003, 7, 90.

55. West, J.E. Remaining Relevant. Qual. Prog. 2009, 40, 62-63.

56. Castka, P.; Balzarova, M.A. A critical look on quality through CSR lenses: Key challenges stemming from the development of ISO 26000. Int. J. Qual. Reliab. Manag. 2007, 24, 738-752. [CrossRef]

57. Karapetrovic, S.; Willborn, W. Integrated audit of management systems. Int. J. Qual. Reliab. Manag. 1998, 15, 694-711. [CrossRef]

58. Liebesman, S. Mitigate SOX Risk With ISO 9001 and 14001. Qual. Prog. 2005, 38, 91-93.

59. Briggs, S.L.K. Do Environmental Management Systems Improve Performance? Qual. Prog. 2006, 39 , 78-80.

60. Block, M.R. ISO 14001 Revision Nears Completion. Qual. Prog. 2004, 37, 77-80.

61. Casolani, N.; Liberatore, L.; Psomas, E. Implementation of Quality Management System with ISO 22000 in Food Italian Companies: Acces la Success. Calitatea 2018, 19, 125-131.

62. Abebe, G.K.; Bahn, R.A.; Chalak, A.; Yehya, A.A.K. Drivers for the implementation of market-based food safety management systems: Evidence from Lebanon. Food Sci. Nutr. 2020, 8, 1082-1092. [CrossRef]

63. Abebe, G.K.; Bahn, R.A. Market-based food safety management systems: Evidence from Lebanon. Food Sci. Nutr. 2019, 8, 1077-1083.

64. Salim, H.K.; Padfield, R.; Chew, T.L.; Syayuti, K.; Papargyropoulou, E.; Mun Hou, T. An investigation of the drivers, barriers, and incentives for environmental management systems in the Malaysian food and beverage industry. Clean Technol. Environ. Policy 2018, 20, 529-538. [CrossRef]

65. Psomas, E.L.; Fotopoulos, C.V.; Kafetzopoulos, D.P. Motives, difficulties and benefits in implementing the ISO 14001 Environmental Management System. Manag. Environ. Qual. 2011, 22, 502-521. [CrossRef] 
66. Idrissi, H.E.Y.E.; Bouami, D.; Cherkaoui, A. Integrated management system: Towards a new approach and a new model. Int. J. Ser. Oper. Manag. 2014, 19, 338-359. [CrossRef]

67. Păunescu, C.; Argatu, R.; Lungu, M. Implementation of ISO 22000 in Romanian Companies: Motivations, Difficulties and Key Benefits. Amfiteatru Econ. 2018, 20, 30-45. [CrossRef]

68. Escanciano, C.; Santos-Vijande, M.L. Implementation of ISO-22000 in Spain: Obstacles and key benefits. Br. Food J. 2014, 116, 1581-1599. [CrossRef]

69. Massoud, M.A.; Fayad, R.; El-Fadel, M.; Kamleh, R. Drivers, barriers and incentives to implementing environmental management systems in the food industry: A case of Lebanon. J. Clean. Prod. 2010, 18, 200-209. [CrossRef]

70. Kussaga, J.B.; Jacxsens, L.; Tiisekwa, B.P.M.; Luning, P.A. Food safety management systems performance in African food processing companies: A review of deficiencies and possible improvement strategies. J. Sci. Food Agric. 2014, 94, 2154. [CrossRef] [PubMed]

71. Zimon, D.; Madzik, P.; Domingues, P. Development of Key Processes along the Supply Chain by Implementing the ISO 22000 Standard. Sustainability 2020, 12, 6176. [CrossRef]

72. Panghal, A.; Chhikara, N.; Sindhu, N.; Jaglan, S. Role of Food Safety Management Systems in safe food production: A review. J. Food Saf. 2018, 38. [CrossRef]

73. Özçakmak, S. A model of hazard and risk analysis for bread production and the awareness of food safety. Qual. Assur. Saf. Crop. Foods 2019, 11, 719-724. [CrossRef]

74. Suvasish Das, S.; Md Shahariea Karim, J.; Parvin, R.; Zahid, M.A.; Paul, D.K.; Elahi, M.T. Development of a HACCP-based approach to control risk factors associated with biscuit manufacturing plant, Bangladesh. Nutr. Food Sci. 2019, 49, 1180-1194.

75. Castka, P.; Corbett, C.J. Governance of eco-labels: Expert opinion and media coverage. J. Bus. Ethics 2016, 135, 309-326. [CrossRef]

76. Heras-Saizarbitoria, I.; Boiral, O. ISO 9001 and ISO 14001: Towards a Research Agenda on Management System Standards. Int. J. Manag. Rev. 2013, 15, 47-65. [CrossRef]

77. Arvanitoyannis, I.S.; Samourelis, K.; Kotsanopoulos, K.V. A critical analysis of ISO audits results. Br. Food J. 2016, 118, 2126-2139. [CrossRef]

78. Reid, J.; Rout, M. Can sustainability auditing be indigenized? Agric. Hum. Val. 2018, 35, 283-294. [CrossRef]

79. Stummvoll, G. Governance through norms and standards: The normative force behind design-led crime prevention. Criminol. Crim. Justice 2012, 12, 377-396. [CrossRef]

80. Uzumeri, M.V. ISO 9000 and Other Metastandards: Principles for Management Practice? Acad. Manag. Exec. 1997, 11, 21-36. [CrossRef]

81. Richardson, A.; Eberlein, B. Legitimating Transnational Standard-Setting: The Case of the International Accounting Standards Board. J. Bus. Ethics 2011, 98, 1-29. [CrossRef]

82. Auld, G.; Gulbrandsen, L. Transparency in Nonstate Certification: Consequences for Accountability and Legitimacy. Glob. Environ. Politics 2010, 10, 97-119. [CrossRef]

83. Ansari, S.M.; Fiss, P.C.; Zajac, E.J. Made to fit: How practices vary as they diffuse. Acad. Manag. Rev. 2010, 35, 67-92.

84. Dietler, D.; Leuenberger, A.; Bempong, N.-E.; Campbell-Lendrum, D.; Cramer, C.; Eggen, R.I.; Erismann, S.; Ferazzi, S.; Flahault, A.; Fletcher, H.A. Health in the 2030 Agenda for Sustainable Development: From framework to action, transforming challenges into opportunities. J. Glob. Health 2019, 9. [CrossRef]

85. Razavi, S. The 2030 Agenda: Challenges of implementation to attain gender equality and women's rights. Gend. Dev. 2016, 24, 25-41. [CrossRef]

86. MacFeely, S. The Big (data) Bang: Opportunities and challenges for compiling SDG indicators. Glob. Policy 2019, 10, 121-133. [CrossRef]

Publisher's Note: MDPI stays neutral with regard to jurisdictional claims in published maps and institutional affiliations. 